ISSN 2745-7168 (DARING)

MUQODDIMA Jurnal Pemikiran dan Riset Sosiologi 2 (1), 2021: 79-98

ARTIKEL

DOI: 10.47776/MJPRS.002.01.06

\title{
Tradisi Pesantren dan Kosmopolitanisme Islam di Masyarakat Pesisir Utara Jawa
}

\section{Pesantren Tradition and Islamic Cosmopolitanism in the Northern Coastal Communities of Java}

\author{
Syamsul Hadi \\ Program Magister Sejarah dan Peradaban Islam \\ Universitas Nahdlatul Ulama Indonesia (UNUSIA) Jakarta \\ Email: syamsulhadi@unusia.ac.id
}

\begin{abstract}
Abstrak
Penelitian ini bertujuan menjelaskan wajah Islam yang bercorak kosmopolitan dan eksistensi pondok pesantren yang terkait pelestarian tradisi-tradisi Islam di masyarakat pesisir. Implementasi nilai-nilai dan ajaran Islam yang toleran terhadap budaya dan kearifan lokal, tentu menjadi perhatian utama pesantren dalam membangun kohesivitas sosialnya. Penelitian sosial ini menggunakan metode kualitatif dengan paradigma konstruktivisme. Penggalian data dilakukan melalui wawancara mendalam ditambah review dokumen atau kajian literatur yang terkait dengan obyek penelitian. Hasil penelitian menunjukkan, bahwa tradisi pesantren telah mengakar kuat di lingkungan masyarakat pesisir utara Jawa seperti upacara Pangwiwahan, Muludan, Manaqiban dan ritual pembacaan Tahlil/Yasin dan Shalawatan yang justru mendominasi dalam upacara adat Slametan atau Kenduren (tradisi lokal). Tradisi tersebut nampak dipengaruhi karakteristik Islam kosmopolitan yang sudah lama berkembang di masyarakat pesisir Jawa, lebih-lebih di lingkungan kota bandar. Budaya kosmopolitanisme dicirikan oleh suasana komunikasi yang cair, terbuka dengan pihak luar dan keramhtamahan. Dan pada perkembangnya waktak kosmopolitanisme ini juga membentuk formasi sosial yang majemuk dalam pemukiman kota, di mana satu sama lain saling menghargai dan memegang kesamaan nilai, saling tepo selira. Terbentuknya corak serta karakter masyarakat demikian tak luput karena pengaruh budaya bandar. Bahwa bandar dan pelabuhan tidak semata tempat pertukaran atau keluar masuknya barang dan manusia. Bahkan di situ pula
\end{abstract}


ada kontak budaya, pertukaran gagasan dan persinggungan gaya hidup para aktor dari berbagai bangsa dengan latar belakang yang berbeda-beda. Berkat kemampuan dalam beradaptasi dengan segala perbedaan dan selektif terhadap kebaruan yang dipilih terbukti menjadikan pesantren berkembang dinamis, namun tetap memiliki pengaruh yang kuat di kalangan masyarakat pendukungnya.

Kata kunci: pesantren, kosmopolitanisme islam, bandar, tradisi lokal

\begin{abstract}
This study aims to explain the cosmopolitan of Islam and the existence of pesantren that related to the preservation of Islamic traditions in coastal communities. The implementation of Islamic values and teachings that are tolerant of local culture and wisdom, of course, is the main concern of pesantren in building social cohesiveness. This social research uses qualitative methods with constructivism paradigm. Data mining was carried out through in-depth interviews plus document reviews or literature studies related to the object of research. The results showed that the pesantren tradition had deep roots in the northern coastal community of Java, such as the Pangwiwahan, Muludan, Manaqiban ceremonies and the rituals of reading Tahlilan / Yasinan and Shalawatan which dominated the traditional ceremonies like Slametan or Kenduren (local traditions). This tradition seems to be influenced by the characteristics of cosmopolitan Islam which has long developed in coastal communities of Java, especially in the bandar environment. The cosmopolitanism culture is characterized by a fluid atmosphere of communication, openness to outsiders and hospitality. So, in the development of this cosmopolitanism character, it also forms a pluralistic social formation in urban settlements, where each other respects and holds the same values, namely tepo selira. The formation of the pattern and character of the community is not spared because of the influence of the bandar's culture. That bandar and ports are not merely places of exchange or entry and exit of goods and people. In fact, there is also cultural contact, the exchange of ideas and the intersection of the lifestyles of actors from various nations with different backgrounds. Because the ability to adapt to all differences and be selective about the chosen novelty, it is proven that the pesantren develops dynamically, but still has a strong influence among the supporting community.
\end{abstract}

Keywords: pesantren, islamic cosmopolitanism, bandar, local traditions

\title{
Pendahuluan
}

Berdasarkan data EMIS Kemenag RI Tahun 2015/2016 terdapat 28.984 buah pondok pesentren yang tersebar di seluruh penjuru Tanah Air dengan total santri mukim kurang lebih 4.290.626 santri. Sebaran lembaga pesantren yang paling banyak di Pulau Jawa yang berjumlah 23.329 buah pesantren atau 82,74 persen, dan yang paling sedikit ada di wilayah Indonesia bagian timur (641 pondok 
pesantren atau 2,75 persen) (http://pendis.kemenag.go.id/index). Merunut sumber historis, lembaga pendidikan Islam yang disebut Belanda partikelir ini pada awal pertumbuhannya berdiri di kota-kota bandar, seperti Gresik, Ampel Denta (Surabaya), Tuban, Lasem dan lain-lain. Dan di kota-kota Bandar niaga ini pula pusat-pusat studi Islam terus berkembang (Madjid 2004). Hingga di kemudian hari seiring ditaklukkannya kerajaan-kerajaan Islam di sepanjang pesisir Pantai Utara Jawa (Pantura) kiai beserta lembaga pesantren yang diasuhnya mulai merangsek ke wilayah pedalaman (Dhofier 1994:13). Disanalah kemudian pesantren banyak yang berdiri di sekitar area perusahaan perkebunan atau pabrik gula seperti pesantren Tebuireng dan pesantren tua lainnya.

Jamak diketahui bahwa karakter lembaga pesantren yang toleran serta menghargai kebudayaan lokal bahkan terbuka terhadap datangnya perubahan dari luar menjadi salah satu alasan terbentuknya watak kosmopolitanisme Islam yang diembannya. Menurut Agus Sunyoto, ciri khas tersebut melekat karena dari sejarah awal kemunculannya lembaga pendidikan indegenious Nusantara ini telah diproyeksikan para pendirinya (Walisongo) sebagai sarana dakwah dalam situasi sosial dan ruang budaya yang saling berdialog; antara ajaran Jawa, HinduBudha dan Islam (Sunyoto 2011). Latar belakang ekologi sosial serta historis di atas menegaskan adanya proses akulturasi dan sintesa budaya serta menjadi suatu argumen terbangunnya setting sosio-kultural di mana wilayah Melayu-Nusantara khususnya Jawa telah menjadi kawasan kosmopolitan.

Menempatkan Jawa sebagai persilangan budaya dengan latar sejarahnya maka pada gilirannya membentuk karakter masyarakat kepulauan yang berciri toleran dan adaptif terhadap pengaruh budaya luar (Lombard 2005). Seperti halnya datangnya ajaran Hindu-Budha pada masa sebelumnya, Islam masuk dan diterima penduduk Jawa bukan dengan cara penaklukkan dan bukan karena oposisi elite, namun sangat mungkin melalui patronase di kalangan elite (Ricklefs 1989:76). Sehingga pada kisaran abad ke-14-16 M, dan pasca runtuhnya imperium Hindu-Majapahit dakwah Islam menyebar hampir ke seluruh kepulauan Nusantara yang relatif berjalan baik, damai dan terus terggalang semakin masif (Madjid 1992).

Menurut Martin van Bruinessen (1995:19), bahwa karakteristik pendidikan pesantren tradisional Indonesia yang terbuka terhadap budaya luar tidak terlepas dari pengaruh ajaran Islam Sunni yang moderat, atau madzhab Ahlussunah wal Jama'ah di samping karena tumbuh di lingkungan masyarakat pesisiran yang relatif cair. Sangat logis kalau mayoritas kiai yang memangku pesantren adalah para ulama pengikut aliran Sunni-Syafi'i. Kalau dirunut dari jejak historisnya secara kebetulan para pendakwah Islam awal yang masuk ke Nusantara adalah para da'i pengembara (kiai lelono) atau orang-orang tarekat serta kaum pedagang yang menyebarkan ajaran Islam Ahlussunnah wal Jamaáh yang bercorak sufistik atau tasawuf (Zuhri 1981). Gelombang misi Islam sufistik ini mula-mula menyebar di tanah Jawa bagian wilayah Pantura melalui hubungan bisnis dan perdagangan, dan dari pusat-pusat Islam di sana kemudian menyebar luas ke daerah-daerah pedalaman di seluruh penjuru negeri (Ricklefs 1989:74). 
Sebagaimana dikatakan Alwi Sihab (2002:23), salah satu ciri Islam sufistik adalah bersifat inklusif dan toleran dengan budaya lokal. Contohnya yaitu pembangunan menara masjid Kudus yang mirip dengan situs candi Hindu khas Majapahit dan gaya arsitektur masjid Mantingan di Jepara merupakan artefak Islam yang menggambarkan kokohnya budaya toleransi serta bukti penghormatan Islam terhadap budaya Hindu dan Tionghoa. Hal ini menunjukkan para juru dakwah di masa awal penyebaran Islam tersebut sangat memahami betul kondisi psikososial penduduk setempat yang masih gemar melestarikan tradisi dan budaya lokal (Salam 1977:36). Karena kemampuan yang dimiliki Islam dalam berdialog dengan budaya lokal (adat Jawa) maupun Hindu-Budha, yang sebenarnya telah mempengaruhi sendi-sendi kehidupan dan watak penduduk pribumi sebelum masa kedatangannya, patut dimengerti kalau sifat kelenturan Islam pada akhirnya mampu menampilkan corak budaya kosmopolitan di Indonesia. Sebuah pola kebudayaan yang membentuk perilaku dan karakter beragama yang toleran terhadap apa yang datang dari luar tadi (Wahid 2007).

Watak kosmopolitanisme Islam yang secara simbolik memang khas dan akomodatif dengan langgam budaya dan tradisi lokal, terutama dalam ruang penyebarannya di kawasan pesisiran pantai utara Jawa. Jika merujuk elaborasi dari Dhofier (1994), nilai-nilai Islam kosmopolitan inilah yang pada dasarnya menjadi rujukan nilai terbentuknya tradisi dan budaya pesantren di lingkungan masyarakat pedesaan. Dari sini pula sifat moderasi (al-wasathiyah) dan kelenturan pesantren (kiai) untuk menerima perubahan yang datang dari luar telah mendapatkan legitimasi. Hal ini selaras dengan kaidah yang berlaku di pesantren; al-Muhaafadhatu 'ala qodim ash-sholeh wa al-akhdzu bi al-jadidi ash-ashlah (mempertahankan tradisi lama yang masih baik dan mengambil tradisi baru yang lebih baik). Karena itu, nampak tidak lazim apabila pesantren menolak ideide pembaruan yang datang dari luar sementara dalam batas kewajaran masih mau menerimanya meskipun dengan penuh kehati-hatian (Horikoshi 1987). Berangkat dari latar belakang di atas, tulisan ini mencoba memberikan jawaban atas pertanyaan: bagaimana rekam jejak historis-sosiologis penyebaran Islam di daerah Pantura yang bercorak kosmopolitan ini menjadi core value dalam misi dakwah serta pondasi untuk pembentukan model pendidikan pesantren di Jawa dan Nusantara pada umumnya.

Tulisan singkat ini bertujuan membahas nilai-nilai kosmopolitanisme Islam yang mempengaruhi karakteristik serta model pendidikan pesantren di pesisir utara Jawa serta tradisi-tradisi lokal yang berkembang dan telah mengakar di lingkungan masyarakat di wilayah Pantura. Penelitian menggunakan paradigma konstruktivisme, yang secara metodologis bersifat subyektif-interpretatif dengan suatu pengembangan model analisis yang bersifat dialektika-hermenetik. Bahwa konstruksi sosial pada ranah individu dapat diperoleh dan diketahui melalui interaksi yang intens di antara peneliti dan subyek yang sedang didalami (Guba dan Lincoln 2009). 


\section{Islam Kosmopolitan: Kasus Pantura Jawa}

Hingga saat ini belum ada ahli sejarah Islam Indonesia yang menyatakan kapan tepatnya ajaran ajaran Islam marambah kawasan pantai utara Jawa. Bukti literatur yang ada masih sebatas "memperkirakan", misalnya suatu analisis yang mengatakan tidak menutup kemungkinan kedatangan Islam di sepanjang kotakota pesisir utara Jawa bisa jadi hampir bersamaan dengan datangnya syiar Islam di daerah Gresik dan sekitarnya, yaitu situs sejarah di Leran Gresik yang ditemukan nisan makam kuno yang bertuliskan nama Syarifah Fatimah binti Maimun (wafat $1082 \mathrm{M})$.

Di masa itu, keberadaan Gresik (Warugasik), Surabaya (Ujung Galuh), dan Tuban (Kambang Putih) merupakan satu rangkaian tujuan perniagaan dalam lintasan jalur rempah yang sangat ramai dan dihubungkan dengan kota-kota pelabuhan dagang di sepanjang pantai utara Jawa seperti halnya pelabuhan Sedayu, Lasem, Juwana, Jepara, Semarang, Cirebon hingga ke pelabuhan Banten serta pelabuhan lainnya di seluruh kawasan Nusantara (Sulistiyono 2017). Lalu lalang armada laut tersebut tidak hanya mengangkut para pedagang berikut barang-barang dagangannya tetapi tidak sedikit para penyiar Islam (muballig) juga ikut menumpang bersamanya (Janutama 2014:92).

Karena diuntungkan letaknya yang strategis di jalur pelayaran dan perdagangan dunia, di antara belahan dunia Timur dan Barat, negeri kepulauan ini tentu banyak mendapatkan pengaruh dari luar, tidak hanya dalam aspek ekonomi dan politik tetapi juga pengaruh sosial dan kebudayaan asing. Lalulalang pelayaran dan perdagangan serta penyebaran misi Islam semakin intens setelah dibukanya jalur sutera melalui daratan antara negeri Romawi dan Tiongkok sehingga menyebabkan rute pelayaran dan perdagangan di kawasan Asia Tenggara semakin berkembang pesat (Janutama 2014:22).

Ditamabah pula posisi geografis yang menguntungkan, yakni datangnya angin muson barat dan timur yang selalu berubah arah dalam tempo selama enam bulan menjadi faktor penting dalam menggerakan moda transportasi laut, yang mana pada waktu itu teknologi perkapalan masih tergantung dengan arah angin. Karena posisinya yang strategis serta kondisi alam kepulauan kita yang tenang, lebih-lebih dengan ketersedian kekayaan alam bumi Indonesia akan rempahrempah dan hasil bumi lainnya yang melimpah ruah serta dijaga penduduk negeri yang ramah, tentu kian menambah daya tarik bagi para pelancong manca negara untuk betah bersinggah di negeri kita.

Suku-suku bangsa yang telah lama mendiami sepanjang perlintasan jalur niaga dan perdagangan dunia ini sudah sejak awal terlibat dan mengambil banyak manfaat, tidak hanya menjalin hubungan dagang antarpulau di seluruh kawasan Melayu-Nusantara dan negara-negara luar, tetapi juga dapat menjalin kerjasama di bidang kebudayaan, sosial dan politik dengan negara-negara luar seperti Tiongkok, Benggali, Campa, Persia, India, Arab dan negara-negara lain (Kayam 1989). Dalam konteks ini, Denys Lombart

(1981:286) menamakan jaringan antar pulau dan antarnegara tersebut sebagai jaringan bahari Nusantara yang 
memasukkan perairan Jawa sebagai perlintasan utama.

Terbentuknya jaringan rempah Nusantara sebagai jalur pelayaran dan perniagaan dunia tidak hanya diramaikan oleh datangnya kapal-kapal asing dari berbagai negara manca, tetapi tidak ketinggalan pula kapal-kapal dagang Jawa dan dari pulau-pulau lain asal Nusantara juga banyak yang berlayar hingga menempuh perjalanan jauh dengan membawa pulang barang-barang dari luar negeri kemudian didistribusikan kembali hingga daerah-daerah pedalaman (Nugroho 2011).

Terhitung sejak permulaan abad ke-13, melalui jaringan bahari atau jalur rempah banyak penyebar Islam merambah jalan dakwah ke tanah Jawa dan tempat-tempat lain di seluruh pelosok kepulauan Nusantara di tengah-tengah kesibukan dalam berdagang (Kayam 1989). Akibat semakin ramainya hubungan perdagangan dengan dunia luar menyebabkan tumbuhnya suatu lapisan aristokrasi pelabuhan yang kuat di pusat-pusat kota bandar pelabuhan, yang tak lain banyak dipegang para saudagar Muslim. Golongan saudagar ini yang disebut Koentjaraningrat (2007:24) sebagai kelas elite yang banyak menyokong perkembangan dakwah Islam di Jawa terutama di kawasan pesisiran, contohnya Nyai Ageng Pinatih penguasa bandar di Gresik dan Ratu Kalinyamat di Jepara.

Penduduk Muslim yang menetap di dekat kota badar niaga tersebut berkumpul dalam satu komunitas yang disebut Kauman (Van den Berg 2020:100). Lokasi kampung Kauman umumnya tidak jauh dengan pusat pelabuhan. Di kota bandar itu pula terdapat komunitas Pecinan, yang letaknya pun saling berdekatan. Bahkan tidak sedikit penduduk lokal (pribumi) dan suku-suku bangsa lain juga tinggal berdampingan di kampung Kauman maupun Pecinan. Buku Carita Lasem memotret sebuah pemukiman Kauman yang berada di tengah-tengah lingkungan Pecinan, bahkan nampak harmoni didiami dari beragam etnis dan suku bangsa lainnya seperti penduduk asal Makasar (Bugisan). Harmoni sosial dapat terjamin karena lekatnya budaya keramahtamahan dibarengi etika tepo seliro sehingga mendorong munculnya episentrum ruang publik yang cair. Barangkali inilah ciri khas kota bandar yang penuh lalu lalang arus manusia dari berbagai latar belakang budaya dari berbagai belahan dunia.

Di lingkungan Kauman ini sudah lazim dibangun semacam gilda atau zawiyah di samping bangunan masjid utama, tentu juga bangunan Kelenteng. Pada persemaian awal Islam di Jawa keberadaan bangunan gilda selain digunakan untuk kegiatan para pengikut tarekat dan guru sufinya, juga digunakan sebagai tempat belajar para santri (penduduk lokal) untuk mendalami ajaran Islam (Madjid 2004). Di dalam kompleks Kauman Tuban misalnya, masjid sekaligus tempat studi keislaman yang pertama kali dibangun adalah masjid Agung pada masa Bupati R. Tumenggung Aryo Tejo (Syaikh Abdurrohman). Bersamaan dengan itu kondisi di kota bandar Tuban beserta kota-kota bandar lainnya seperti Lasem, Sedayu, Gresik dan Ujunggaluh (Surabaya) terhitung sangat ramai disinggahi oleh para saudagar Muslim dan para penyebar agama Islam yang datang dari Arab, Persia, Turki, Gujarat, Campa, Cina, Benggali dan India. Selain Tuban dan Lasem, prototipe kosmopolitanisme Nusantara bisa kita jumpai di Kota Kudus dan Demak yang 
menjadi pusat pemerintahan Kesultanan Islam pertama di Nusantara.

Bersumber dari telaah toponimi desa-desa dan kampung di wilayah Kota Kudus setidaknya dapat digambarkan suatu formasi sosial yang unik daripada terbentuknya tempat-tempat pemukiman penduduk yang plural serta sejarah yang melatarinya. ${ }^{1}$ Unik karena formasi sosial itu terbentuk dengan latar belakang penduduk yang sangat beragam dari asal usul kebudayaan maupun profesi yang dijalananinya, misalnya ada yang dari India (Pakojan), Arab dan Persia (Kauman), Tiongkok (Pecinan), Sumatera (Damaran), Kajeksan, Demangan serta unsurunsur lain yang dapat menyatu dalam komunitas sosial. Faktor keragaman sosialbudaya serta solidaritas antar etnik yang relatif mapan (harmoni karena tertib sosial terjamin) pada gilirannya mengantarkan kota santri atau kota keretak di Jawa Tengah ini menjadi episentrum kota dagang yang mapan hingga seperti apa yang dapat kita saksikan sampai hari ini.

Lembaga kemasjidan maupun langgar yang ada, selain menjadi pusat peribadatan jamaah masjid juga berfungsi sebagai pusat studi keislaman yang telah berjalan sejak waktu dulu hingga sekarang. Pada era kejayaan kota-kota pesisir di awal masuknya Islam, para guru sufi dan guru ngaji biasanya memilih tinggal di sekitar lingkungan masjid dan langgar di tiap kota bandar tersebut. Di samping aktif berdakwah dan menyelenggarakan kegiatan rutin pengajian keagamaan para guru ngaji tersebut tetap aktif menjalankan profesinya sebagai pedagang (Madjid 2004:17).

\section{Jalur Rempah dan Persemaian Islam Pesisiran}

Di sepanjang pesisir utara Jawa, terutama di pingir bandar pelabuhan merupakan kawasan yang mengalami proses islamisasi secara intensif dan kontinu. Para juru dakwah yang datang dari negeri-negeri Islam mengemban misinya melalui perdagangan. Dari sinilah jaringan bahari Nusantara memainkan peranan penting dengan menghubungkan pulau Jawa, khususnya daerah-daerah di pesisiran dengan dunia luar, yang semakin ramai setelah para pedagang Islam yang berasal dari Arab, Persia, India, Istambul, Gujarat, Cina dan Campa, ditambah partisipasi para pedagang antar pulau yang turut andil meramaikan perdagangan di jalur rempah. Meningkatnya volume pelayaran dan perniagaan di kawasan tersebut tidak hanya diramaikan oleh kapal-kapal asing dari berbagai negara manca, namun tidak ketinggalan pula kapal-kapal dagang Jawa juga banyak yang berlayar hingga menempuh perjalanan jauh ke Gujarat, Madagaskar, Persia dan Arab dengan membawa pulang barang-barang dari luar negeri untuk didistribusikan ke pasar-pasar lokal atau ke daerah-daerah di pedalaman.

$1 \quad$ Di wilayah Kudus terdapat nama-nama desa atau perkampungan yang mempunyai makna dan terikat dengan sejarah dan peristiwa ("tetenger") pada tempat tersebut di masa lalu, seperti Desa Kauman Menara, Desa Kajeksan, Desa Langgar Dalem, Desa Janggalan, Desa Sunggingan, Desa Demangan, Desa Pekojan, Kampung Pecinan, Desa Damaran. Desa Sumur Tulak, Desa Paduraksan, Desa Demangan, Desa Demakan, Desa Kalinyamatan, Desa Karetan, dan nama-nama desa lain yang masing-masing memiliki latar sejarah sendiri (Sri Indrahti 2012: 47-48). 
Bersamaan meluasnya pengaruhimperium Hindu-Majapahit dapat dijelaskan pula perkebangan yang paralel yaitu partisipasi orang Jawa dalam kegiatan perdagangan di lautan India yang didominasi para pedangan Muslim (Dhofier 1994:4). Pada kesempatan lain Johan Henrik Meuleman (1999:145) menyakini, paling tidak dalam pentas globalisasi awal, wilayah Asia Tenggara tidak hanya memainkan peranan pasif, oleh karena proses tersebut merupakan hasil interaksi antara aktor, di pusat dan keseluruhan pembangunan sistem global. Setelah hubungan perdagangan memainkan peranan penting dalam ekspansi Islam dan unifikasi berbagai dunia Muslim, yang pada waktu itu sudah terlibat sejak awal kemunculan jaringan kerja. Tidak dapat dipungkiri bahkan kemudian berlanjut pada hubungan ilmiah-kependidikan dan organisasi mistik yang sudah barang tentu aktif pula membangun dan memperkuat kesatuan sosial yang ada. Hal itu berarti, aktivitas perdangangan dan dakwah yang berjalan pada masa itu sudah relatif mapan (melembaga) dan terus merambah ke pelosok-pelosok pedalaman yang secara kelindan menyemaikan corak kebudayaan Islam Nusantara yang tak sepenuhnya warna lokal di dalam kehidupan masyarakat yang plural.

Sejak permulaan abad ke-13 M, melalui jaringan bahari (jalur rempah) di masa awal para penyebar Islam (muballigh) merambah jalan dakwah ke tanah Jawa dan tempat lain di seluruh penjuru kepulauan Nusantara di sela-sela aktivitas perniagaan (Kayam 1989). Semakin ramainya hubungan perdagangan dengan dunia luar mengakibatkan tumbuhnya suatu lapisan aristokrasi di kota bandarpelabuhan yang kuat. Mereka inilah kelas elite yang sesungguhnya banyak menyokong bagi perkembangan dakwah Islam di tlatah Jawa (Koentjaraningrat 2007). Secara politik berdiri Kesultanan Islam Demak juga tidak lepas dengan peranan golongan aristrokasi di badar. Sepertinya kondisi sosial-politik ketika itu juga sangat memungkinkan masing-masing kota bandar yang masih memiliki otoritas kekuasaan yang relatif kuat, kurang lebih, telah terjadi konsolidasi perdagangan dengan politik dan agama sekaligus. Dalam pengertian lain, kegiatan dagang, kekuasaan dan agama adalah tiga hal yang saling berkaitan dan menunjang dalam proses islamisasi di Jawa (Fachry Aly 1996:259).

Dengan perluasan jaringan yang dimiliki lingkaran elit pelabuhan pada gilirannya semakin menguatkan ikatan kelas mereka sehingga dapat mendukung aktivitas dakwah melalui jalur struktural, yaitu dengan pendekatan kepada para penguasa lokal yang menguasasi wilayah pesisiran. Selaras yang dikatakan Ricklefs (1989) pelan-pelan dan massif Islam masuk dan terus merambahkan pengaruhnya ke seluruh penjuru Nusantara. Bukan dengan cara penaklukkan dan bahkan tanpa oposisi elite, akan tetapi lebih memilih cara damai dan mengedepan hubungan kemanusiaan dan keadaban.

Kedatangan misi Islam yang toleran, selain kemampuannya berdialog secara baik dengan budaya lokal (adat Jawa) maupun dengan agama-agama sejarah sebelumnya (Hindu-Budha), maka sudah sejak awal banyak mempengaruhi sendisendi kehidupan masyarakat setempat yang pada gilirannya mampu menampilkan corak budaya Islam pesisir yang bersifat kosmopolitan tanpa menghilangkan anasir-anasir lokalitas

(Madjid 2004; Wahid 2007). Sebut saja misalnya, 
upacara adat Pangwiwahan (upacara daur hidup) meskipun dalam prakteknya saat ini nilai-nilai Islam begitu dominan, namun prosesinya tetap mempertahankan simbol-simbol Jawa.

Corak Islam kosmopolitan secara simbolik memang khas dan identik dengan corak budaya Jawa, terutama ruang penyebarannya di sepanjang wilayah pesisiran utara. Budaya kosmopolitan ini yang pada dasarnya menjadi rujukan nilai dalam membentuk karakter santri dan terbentuknya tradisi pesantren secara luas (Dhofier 1984). Seperti sifat moderat/wasatiyah dalam beragama atau kelenturan pesantren (kiai) untuk menerima perubahan yang datang dari luar sebenarnya telah mendapatkan legitimasi, tanpa harus disertai debat panjang palagi sampai pertentangan fisik yang berdarah-darah. Karena melalui proses dialog antar budaya secara intens akhirnya menjadi babakan sejarah tersendiri untuk menghasilkan suatu produk kebudayaan baru yang dianggap sesuai dengan kebutuhan masyarakat lokal.

Sepanjang budaya lokal tersebut tidak bertentangan dengan prinsip-prinsip teologis, aturan syariat dan etika Islam maka asimilasi maupun akulturasi antar budaya tetap berlangsung tanpa seleksi yang ketat. Apabila ada unsur-unsur yang dimungkinkan bertentangan dengan prinsip-prinsip di atas selanjutnya perombakan dilakukan secara pelan-pelan sehingga tidak menimbukan kegaduhan di masyarakat, seperti yang terjadi pada tradisi kenduri, yang sebelumnya berupa pengadaan sesaji berupa makanan, jajanan pasar dan uborampe lainnya untuk dipersembahkan kepada dahyang (roh gaib) sebagai bentuk pemujaan. Kemudian diinisiasi kembali oleh Sunan Kalijaga menjadi budaya slametan yang sepanjang prosesinya tidak luput dengan bacaan ayat-ayat suci Al-Qur'an, shalawat Nabi saw, kalimat-kamlimat thayyibah dan diakhiri dengan pembacaan do'a salamah demi pengharapan datangnya keselamatan dari Allah Swt untuk para hamba yang suka mumuja-Nya (Hasyim 1974:30).

Sejak awal kontak budaya inilah maka tak ayal lagi, karakter Islam pesisir seperti yang tumbuh di kawasan kota bandar-pelabuhan menjadi lekat terwarnai kultur kosmopolitanisme, pragmatisme, kolektivisme dan individualisme (Zamjani dan Faishal 2004). Oleh karena itu masyarakat Muslim di seputar bandar pelabuhan pada umumnya lekat dengan karakter yang terbuka terhadap informasi yang datang dari luar. Lata sosio-kultural demikian yang pada gilirannya berkontribusi besar pada pembentukan karakter, sikap dan perilaku keagamaan serta kebudayaan pesantren dan masyarakat di tingkat basis yang menjadi pendukung setianya. Berbeda dengan karakter masyarakat Muslim pedalaman, kaum santri pesisiran relatif cair, adaptif dan toleran terhadap budaya lokal maupun yang datang dari luar.

Barangkali karena proses akulturasi dan asimilasi yang berlangsung secara intens dan alamiah selama berabad-abad sangat wajar apabila di lingkungan pesantren dan masyarakat pendukungnya di kawasan bandar niaga tersebut terbangun relasi sosial antargolongan yang cair dan dinamis. Seakan-akan tidak mempermasalahkan perbedaan etnis dan asal usul kebudayaan, tetapi unsurunsur yang ada dapat saling mendukung yang mencerminkan kuatnya pluralitas 
budaya dan heterogenitas politik, contohnya harmony social yang terbangun di lingkungan basis masyarakat santri di Lasem dan kota-kota bandar lainnya. Bahkan menampakan unsur budaya kosmopolitan yang dominan dan mengagumkan, dalam mana suasana kehidupan sosial dan beragama nampak elektik dan saling mengahargai satu sama lain. Karakter seperti inilah yang sebenarnya menjadi ciri khas kaum pesantren tradisional pada umumnya sehingga cenderung menampakan sikap beragamaan yang moderat (al-wasathiyah) (simak, penjelasan Wahid, 2007:3).

Menurut hemat penulis, corak dan penampilan Islam kosmopolitan di kawasan pesisiran Jawa karena adanya faktor-faktor pembentuknya, yaitu; (a) posisi geografis kawasan pesisir yang terbuka untuk terjadinya kontak budaya, yaitu perjumpaan budaya lokal dengan budaya luar atau manca negara; (b) Wilayah bandar merupakan tujuan singgah para pengemban misi dakwah (muballigh) dari beragam bangsa di dunia sebelum mereka berkeliling mengunjunggi tempattempat di daerah pedalaman; (c) Komunitas bandar adalah area komunikasi yang cair sehingga dialog ataupun udar gagasan dapat berlangsung reltif demokratis dan tanpa terhalang sekat-sekat dan kemapanan lapisan sosial yang rigid; (d) Dalam perkembangnnya di pusat-pusat keislaman (pesantren) juga tersedia sumber-sumber referensi keislaman yang digunakan para ulama yang berasal dari berbagai pusat-pusat studi Islam di dunia seperti dari penulis kitab-kitab klasik yang berasal dari Makkah, Madinah, Persia, India, Andalusia, Kurdistan, Yaman, Syiria, Lebanon di samping karya-karya intelektual dari para ulama/ kiai kalangan pribumi sendiri. Bahkan jejaring dan sanad ilmu dan tarekat yang diamalkan di pesantren-pesantren tradisional berasal dari berbagai belahan dunia yang menunjukan sifat kosmopolitanisme Islam di Nusantara dan Asia Tenggara pada umumnya. Tak ada keraguaan lagi soal ketersambungan sanad keilmuan dan praktek tarekat utama yang dimiliki kalangan pesantren di Nusantara dipercaya berasal dari pusat-pusat keilmuan Islam dunia seperti Mekah, Madinah, Bukhara, Khurasan, Samarkand, India, Yaman dan Persia (Lombard 2005:136).

Bertempat yang tak jauh dari lokasi bandar pelabuhan atau di wilayah sekitarnya para penyebar Islam dan sekaligus berprofesi sebagai pedagang yang singgah kemudian menetap beberapa lama kemudian berkelana ke penjuru negeri. Sehingga dikemudian hari dikenal sebagai kiai lelono. Ada pula sebagian yang berdawah dan menetap di sekitar area pelabuhan dengan mendirikan bangunan zawiyah atau pesantren sebagai pusat pendidikan Islam seperti yang dilakukan Syaikh Maulana Malik Ibrahim (Sunan Gresik) yang membangun pesantrennya tak jauh dari lokasi pelabuhan Gresik. Begitu pula yang dilakukan Syaikh Mahdum Ibrahim (Sunan Bonang) yang membangun zawiyah di dekat pelabuhan Patuk Regol di Desa Binangun Lasem.

Prototipe pendirian pondok pesantren yang jarak lokasinya dekat dengan bandar pelabuhan tersebut tidak sulit menemukan situs peninggalannya, bahkan beberapa di antaranya masih mudah ditemukan oleh generasi santri saat ini. Pada perkembangan selanjutnya, lokasi yang tak jauh dari bandar pelabuhan lazimnya terdapat desa atau kampung santri, karena di situlah sejak puluhan bahkan 
ratusan tahun silam hingga era sekarang telah berdiri komunitas santri beserta kegiatan kepesantrenan yang masih aktif dan menjadi muara rujukan masyarakat umum serta basis pendukungnya. Sekedar contoh, pesantren Makam Agung yang letaknya tidak jauh dari pelabuhan Kambang Putih Tuban. Pesantren di Desa Sodetan dan Sumber Girang yang jarak dekat dengan berjalan kaki ke lokasinya karena berdekatan dengan bekas pelabuhan Kairingan dan galangan kapal Dasun di Kota Bandar Lasem. Termasuk keberadaan Buntet Pesantren maupun pondok Arjowilangun yang berlokasi beberapa kilometer dari kota Bandar Cirebon.

Barangkali di tempat-tempat bandar pelabuhan lain di pula Jawa juga tidak terlalu sukar menemukan situs bangunan pesantren yang tak jauh beda. Berawal dari pusat-pusat pendidikan pesantren yang berada di bandar-pelabuhan ini pada saat perkembangannya kemudian tersebar para santri lulusannya yang kemudian hari mengampu pesantren di beberapa daerah yang tersebar di pulau Jawa bahkan di luar daerah Jawa. Ketika mengomentari sebaran santri didikan pesantren AlHidayat Lasem misalnya, Denys Lombard (2005:148) mencatat, "Bila dicatat di atas peta, dari keterangan yang teliti itu, tampil dengan jelas luasnya salah satu dari sekian banyak jaringan Muslim yang telah kami bicarakan di sini".

\section{Gelaran Tradisi Pesantren di Lingkungan Masyarakat}

Eksistensi lembaga pesantren bisa dipastikan akan hilang tertelan zaman apabila ia tidak memiliki akar tradisi yang kuat di lingkungan masyarakat pendukungnya. Menurut penilaian Abdurrahman Wahid (2007), keberlangsungan lembaga pesantren sangat ditentukan oleh seberapa jauh fungsi atas kemampuannya untuk memberikan jawaban konkrit terhadap tantangan dan perubahan di bidang pendidikan, di samping keberhasilannya dalam pembentukan nilai-nilai dan normanorma di tengah-tengah kehidupan masyarakat dapat dilakukan secara efektif dan berkesinambungan, selain itu kelincahan pesantren dalam merespon perubahan sosio-kultural dan politik yang sedang terjadi. Sangatlah wajar apabila keberadaan pondok pesantren di tengah-tengah masyarakat memiliki tiga fungsi utama dan termasuk urgen, yaitu; (i) tempat untuk mendalami ilmu-ilmu dan mengamalkan ajaran Islam (tafaqquh fi ad-din), (ii) pembudayaan nilai-nilai agama dalam ranah sosial melalui pemeliharaan tradisi Islam, dan (iii) mempersiapkan kader ulama/ kiai sebagai pewaris keberlanjutan tradisi pesantren di masyarakat (Dhofier 1994).

Pelestarian tradisi pesantren di tengah-tengah kehidupan masyarakat tidak sekedar artikulasi simbolik daripada nilai-nilai Islam ansich, tetapi ia merupakan bagian dari pengukuhan identitas yang membedakan antara tujuan pendidikan pesantren dengan institusi pendidikan lain di Tanah Air. Meminjam teoristrukturasi Anthony Giddens (1984), bahwa tradisi dan budaya pesantren merupakan struktur yang secara otomatis mempengaruhi perilaku kehidupan santri (social practices). Baginya struktur umpama jejak memori yang memang mempengaruhi tindakan sosial si aktor. ${ }^{2}$ Beberapa varian kearifan tradisi pesantren yang mencerminkan

2 Struktur dimaknai Giddens (1984) seperti jejak-jejak memori, dan sifatnya bukan berada di luar individu-individu, melainkan berada secara internal dan melekat dalam diri individu-individu yang kemudian muncul dalam bentuk praktik-praktik sosial. Dia pun kembali menegaskan, bahwa struktur berupa "rules and resourcer" (tata aturan dan sumberdaya), yang selalu diproduksi dan direproduksi, serta memiliki relasi dualitas dengan agensi, dan melahirkan berbagai praktik sosial 
hasil proses dialog antarbudaya yang hingga hari ini tetap dilestarikan di kalangan masyarakat pesantren di antaranya adalah:

Pertama, pendidikan budi pekerti/tatakrama. Suatu bentuk etika kepatuhan antara murid/santri kepada guru (kiai). Menurut Agus Sunyoto (2011:95), ajaran tatakrama piwulang Gurubhakti merupakan tatakrama murid (cantrik) yang sebelumnya pernah dipraktikkan dalam kehidupan dukuh atau ashram (lembaga pendidikan SyiwaBudha). Ajaran tersebut menyangkut tata tertib di lingkungan pendidikan, sebagai sikap hormat dan sujud bhakti kepada sang Resi yang wajib dilakukan para cantrik terhadap guru yang mendidiknya. Pola relasi etis antara guru-murid ini tidak hanya mencerminkan hubungan fisik-lahiriah semata, akan tetapi juga menyangkut relasi batiniah sehingga ridlo (kerelaan hati) sang guru adalah pengharapan utama bagi murid untuk memperoleh kesuksesan dalam belajar agama (berkahe ilmu). Dengan demikian ilmu yang dipelajari santri dapat bermanfaat bagi diri dan masyarakat.

Di kalangan kaum santri, sikap hormat atau tradisi kepatuhan (tawadhu') terhadap guru/kiai adalah salah satu nilai pertama yang ditanamkan pada setiap santri karena dianggap bagian integral dari ilmu yang akan dikuasai. Pada tataran praksis tardisi kepatuhan tersebut diperluas kepada baginda Rasul SAW, keluarga beliau, para sahabat, kepada pendiri dan pengajar tarekat (mursyid) dan para pengarang kitab kuning (mushannif) yang dipelajari santri bahkan kepada orang-orang yang dianggap suci atau waliyullah yang dianggap punya kelebihan karamah (Tan 2014).

Untuk menunjukkan bukti penghormatan kepada mereka yang patut dimuliakan itu kaum santri merealisasikannya melalui tradisi kirim do'a atau "hadiah" surat al-Fatihah sebelum balah kitab kuning dimulai. Pada tiap malam jum'at diadakan pembacaan riual barzanji/dziba'iyah (Maulid al-Rasul), shalawatan, burdah, ratib al-'athos dan ratib al-hadad dan pembacaan manaqib Syaikh Abdul Qodir al-Jailani dan berkirim do'a atau tahlilan. Termasuk melestarikan ziarah kubur serta mengadakan upacara penghormatan guru pada even tahunan (haul). Haul adalah upacara keagamaan untuk mengenang jasa serta menghormati sang tokoh panutan pada setiap hari wafatnya pendiri dan para pengasuh pesantren yang telah meninggal dunia. Selain dilakukan kegiatan yang bersifat ritual-spiritual, peringatan Haul Masyayikh kerap diikuti oleh rangkaian kegiatan yang tergolong profan dan tetap mendidik seperti lomba-lomba dan pameran karya seni santri.

Kedua, adalah tradisi tirakat (berupa pengorbanan fisik) yang lazim di kalangan kaum santri disebut riyadhah, misalnya melakukan apa saja yang diperintahkan oleh guru (kiai) yang bernilai dan dianggap tidak melanggar normanorma susila maupun agama. Jadi, berkhidmah kepada kiai dan pesantren adalah bagian dari perilaku riyadhah. Tujuan mengamalkan laku tirakat atau riyadhah yaitu dalam rangka mencari barokah kiai.

Bentuk lain laku riyadhah dapat pula merupakan proses ritual-spiritual di samping menjalani ketentuan wajib dalam beribadah sehari-hari seperti memperbanyak sholat sunnah dan wirid di malam hari, menjalani puasa sunah (dawud, senin kamis, yaumul bith, dll) ataupun melakukan puasa khusus yaitu puasa ngrowot (kalau sedang berbuka atau sahur hanya boleh makan polo pendem atau

(social practices) sebagaimana yang disebut tindakan sosial. Jadi, struktur sosial pada dasarnya adalah suatu kondisi sosial yang dapat mempengaruhi pikiran, sikap dan tindakan aktor ataupun agen. Lihat selengkapnya, Anthony Giddens, "The Constitution of Society: Outline of The Theory of Structuration", Cambridge: Polity Press, 1984. 
umbi-umbian) dan puasa mutih (kalau buka dan sahur hanya makan nasi dan air putih secukupnya).

Lazim berlaku di kalangan santri bahwa kegiatan riyadhah atau laku tirakat semata dimaksudkan untuk mencari ridlo rahmat Allah Swt. Dengan demikian tradisi tirakat yang berupa perilaku bhakti atau sikap ketundukan penuh atas perintah guru dalam laku tirakat (riyadhah), menurut pandangan Gus Dur (Abdurrahman Wahid), bahwa tradisi tersebut ditengarai berasal baik dari praktikpraktik mistik (sufisme) dari Muslim Timur Tengah contohnya yaitu perilaku kefanaan diri (tafani'). Namun, pola ketaatan relegio- etis tersebut, yaitu menjaga hubungan baik di antara guru dan murid pada masa sebelum datangnya Islam sebenarnya juga telah dikenalkan di kalangan penduduk lokal/pribumi, misalnya pada tradisi pandito (Wahid 2007:242).

Ketiga, yaitu tradisi pengajian (majelis taklim) dengan mengambil referensi kitab kuning karya ulama salaf (classical Islamic texts). Karya ilmiah yang ditulis para ulama salaf yang berotoritas tersebut meliputi bidang ilmu tafsir, hadits, fiqh (yurisprudensi), akhlaq-tasawuf (etika Islam), aqidah (teologi), Nahwu-Shorof (ilmu alat) dan lain-lain. Apabila dicermati lebih jauh, berdasarkan pengambilan sumber-sumber referensi kitab klasik keagamaan yang ditulis para ulama Ahlussunnah wal Jama'ah dari berbagai belahan dunia Islam di samping karangan para ulama/ kiai di dalam negeri sendiri, maka menurut Taufik Abdullah (1996:113) hal tersebut menandakan suatu contoh yang amat jelas dan nyata tentang sifat kosmopolitanisme pesantren di Indonesia. Di antara beberapa contoh kitab kuning yang digunakan sebagai rujukan dalam pengajian di pesantren di pesisir utara Jawa dapat diperiksa penjelasan tabel di bawah ini.

Tabel 1

Jenis-jenis Kitab Kuning Yang Menjadi Rujukan Dalam Majelis Taklim

\begin{tabular}{cllc}
\hline No. & Nama Kitab & Nama Pengarang & Bidang Ilmu \\
\hline 1. & Tafsir Al-Jalalain & $\begin{array}{l}\text { Syaikh Jalaluddin as-Syuyuthi \& } \\
\text { Syaikh Jalaluddin al-Mahalli }\end{array}$ & Tafsir \\
2. & Jawahir al-Bukhari & Syaikh Musthofa Muhammad & Hadits \\
3. & Al-Arba'in an-Nawawi & Imam Nawawi Banten & Hadits \\
4. & Bulughu al-Marom & Syaikh Ibnu Hajar al-Asqolani & Hadits \\
5. & Safinat an-Najaa & Syaikh Salim bin Sumair & Fiqh \\
6. & Fath al-Qarib & Syaikh Ibnu Qosim Al-Ghozzi & Fiqh \\
7. & Aqidah al-Awam & Sayyid Ahmad al-Marzuqi & Aqidah \\
8. & Jauhar at-Tauhid & Syaikh Ibrahim al-Laqqoni & Aqidah \\
9. & Ta'lim al-Muta'allim & Syaikh Burhanuddin Az-Zarnuji & Akhlak \\
10. & Bidaayat al-Hidayah & Imam al-Ghozali & Akhlak \\
11. & Al-Jurumiyah & Sayid Ahmad bin Zaini Dahlan & Nahwu \\
12. & Al-Fiyah ibnu Malik & Syaikh Muhammad Jamaluddin & Nahwu \\
13. & Al-Amtsilah at-Tashrif & Kiai Ma'shum Ali Jombang & Shorof \\
14. & Nadlm al-Maqshud & Syaikh Ahmad al-Thahthawi & Shorof \\
\hline
\end{tabular}

Sumber: Dieloborasi dari data Syamsul Hadi (2017:89). 
Dengan menggunakan referensi kitab kuning sebagaimana yang tertera pada tabel di atas dengan sendirinya santri atau masyarakat yang mengkuti majelis taklim kiai otomatis sudah diperkenalkan pemikiran para ulama dari kalangan Tanah Air, Makah dan Madinah (Haramain), termasuk karya-karya dari belahan dunia Islam lain; dari Bagdad, Hadramaut, Kurdistan, Yaman, MalabarIndia bahkan Andalusia-Spanyol, seperti pengarang magnum opus ilmu nahwu (gramatika Arab), Syaikh Muhammad Jamaluddin bin Abdillah bin Malik al-Thay al-Andalusiy (w. 673).

Begitupun patut diketahuai bahwa buku-buku referensi keislaman standar (al-kutub al-muktabar) yang dimaksud merupakan karya agung para inteletual Muslim yang telah memiliki integritas dan menganut paham Islam Alussunah wal Jama'ah ～(van Bruinessen, 1995:17). Menurut Seyyed Hossein Nasr (1987:165) karya-karya intelektual yang lazim dikaji di kalangan kaum santri tersebut mayoritas ditulis pada abad pertengahan Islam atau sekitar abad ke-8 dan $9 \mathrm{H}$ (abad 14 dan $15 \mathrm{M}$ ) bahkan pada masa sebelum itu, yang diperkira-kan sekitar periode awal sejarah intelektual Islam.

Keempat, yaitu pewarisan tradisi literasi huruf pegon dan maknogandul. Literasi kitab kuning dalam bentuk Arab pegon dan makno gandul merupakan cirikhas yang melekat pada tradisi pendidikan Islam indigenous yang sudah berabad-abad dilestarikan di kalangan santri Nusantara. Dalam konteks ini, jadi yang dimaksud penggunaan istilah Arab pegon yaitu akulturasi simbol bacaan antara konsonan Arab yang dilengkapi vokal Hijaiyah dengan menyesuaikan penggunaan bahasa lokal seperti bahasa Melayu, Jawa dan Sunda (Fikri, 2014). Adapun makna gandul adalah pemberian makna atau arti kosa kata beserta simbol kebahasaannya pada teks Arab gundul yakni dengan posisi tulisan menggantung (istilah santrinya ngesahi kitab).

Hingga sekarang ini di lingkungan pesantren dapat kita temukan jenis-jenis kitab kuning yang dijadikan rujukan, antara lain: (a) kitab kuning gundulan yaitu tulisan berbahasa Arab tanpa diberikan syakal harakat dan makna; (b) kitab kuning dengan berbahasa Arab tapi telah diberikan makna gandul; (c) kitab kuning dengan penulisan huruf pegon berbahasa Melayu; dan (d) kitab kuning dengan penulisan huruf pegon dengan berbahasa daerah (Jawa dan Sunda). Di Jawa dan Sunda kitab kuning umumnya ditulis dengan menggunakan bahasa daerah. Sedangkan di luar pulau Jawa rata-rata di tulis menggunakan Bahasa Melayu seperti yang banyak kita jumpai di pulau Sumatera dan Kalimatan bahkan di Bima dan Sumbawa.

Secara sosiologis, pengunaan Bahasa Melayu dalam lingkungan bisnis dan akademis sejatinya memperkokoh relasi sosial antaretnis yang leluasa seperti pada saat ini telah memberi sumbangan berharga bagi integrasi Indonesia, yakni lingua franca, sebagai perantara komunikasi efektif yang mampu menjebatani keragaman bangsa Indonesia. Penggunaan bahasa Melayu "pasar" sebagai lingua franca memilki akar dari bahasa yang berkembang di Riau kepulauan dan menyebar luas ke seluruh nusantara terutama melalui perdagangan (Nugroho 2016:4). Sedangkan Bahasa Melayu "standar" lazim digunakan sebagai bahasa akademis karena sebagaian besar ulama Nusantara menuliskan ide-ide dan pemikiran keagamaan 
dengan huruf pegon, yaitu aksara Arab yang berbahasakan Melayu.

Terakhir adalah, penanaman nilai-nilai kepesantrenan di lingkungan masyarakat sekitar melalui penyelenggaraan upacara adat setempat. Banyak lembaga dan budaya lokal yang telah berkembang di masyarakat basis menjadi sarana penanaman nilai-nilai pesantren seperti tradisi slametan atau kenduri. ${ }^{3}$

Penyelenggaraan tradisi upacara adat Jawa yang berlaku di kalangan masyarakat santri misalnya tradisi slametan atau kenduri merupakan ritus pembacaan doa' yang dimulai dengan pembacaan ayat-ayat suci Al-Qur'an, sholawat Nabi, kalimah thayibah (jenis-jenis dzikir tertentu) kemudian diakhiri dengan membaca do'a salamah (meminta keselamatan kepada Allah, Tuhan Yang Maha Kuasa). Prosesi religi tersebut sengaja dimaksudkan untuk mengiringi sedekah atau shodaqoh yang berupa makanan dan jajanan dari yang punya gawe atau sohibulhajat. Kesatuan sistem religi Jawa-Islam tersebut sudah lazim disebut tradisi berkatan (memohon barokah; bertambahnya nilai kebaikan hidup) demi mencari ridlo Allah Swt..

Dalam konteks ini pula budayawan Jawa, Kuntowijoyo (2008) menerangkan bahwa prosesi upacara adat Jawa yang sudah banyak dipengaruhi Islam ini umumnya untuk mengiringi upacara daur hidup seseorang (Jawa; adat pangiwahan). Tujuan dari pada upacara adat tersebut tak lain untuk diniatkan supaya seseorang atau keluarga besar yang sedang dido'akan secara bersama-sama ini diharapkan selalu mendapatkan rahmat serta keselamatan dari Sang Khalik, pencipta alam dan seisinya.

Di lingkungan pedesaan Jawa, bahkan pula berlaku di masyarakat yang bermukim di kota, penyelenggaraan upacara slametan atau kenduri biasanya dipimpin seorang kiai (orang desa memanggil modin) atau ustadz lulusan pesantren. Tradisi slametan lazimnya dilaksanakan dalam rangka mensyukuri moment lingkaran hidup yang meliputi peristiwa: (1) upacara usia kehamilan empat bulan (mapati) dan tujuh bulanan (mintoni atau tingkeban), (2) upacara potong rambut si bayi yang pertama kali (selapanan), (3) upacara pemberian nama bayi (walimah at-tasmiyah), (4) upacara untuk bayi yang mulai pertama kali menyentuh tanah (setundun), (5) upacara untuk sunatan anak (walimah al-khitan), (6) upacara untuk akad nikah atau ngunduh mantu (walimah al-'urs)), dan (7) upacara mengirim do'a kepada orang yang meninggal dunia, dan atau yang lebih dikenal dengan istilah tradisi Tahlilani atau Yasinan (Kadiran 2007).

Demikian pula ritual-keagamaan yang dilaksanakan di luar ritus lingkaran hidup manusia, seperti upacara adat ketika di awal musim tanam dan panen padi di sawah, upacara bersih desa (nyadran), sedekah laut (petik laut) dan yang lainnya. Beragam jenis upacara adat tersebut diselenggarakan dengan tujuan untuk mencari hidup berkah dan keselamatan dari Allah Swt. sebagai Sang Pencipta dan

3 Menurut Umar Hasim, Sunan Kalijaga merupakan orang yang pertama kali berhasil menginisiasi bentuk akulturasi budaya sekaligus perombakan terhadap tradisi dan budaya lokal tersebut yang sebelum agama Islam datang telah dijalankan penduduk pribumi yang diiringi dengan pembacaan mantera-mantera tertentu dan disertai pengadaan sesaji berupa makanan dan jajanan pasar, Baca, Umar Hasyim, “Sunan Kalijaga”, Kudus: Menara Kudus, 1974, h. 30. 
Pelindung jagad raya.

Dalam konteks ini peranan kiai pesantren bertugas mengarahkan kepada umatnya supaya ritus dan upacara yang diinisiasi berdasarkan budaya lokal tersebut tidak bercampur aduk dengan hal-hal yang berbau kurafat dan syirik, karena dinilai telah melenceng dari syariat Islam atau bertentangan dengan prinsip-prinsip tauhid (akidah). Dengan begitu upacara adat yang bersendikan agama tetap berjalan sesuai harapan dan kebutuhan masyarakat dalam memenuhi hasrat kebudayaannya, tanpa sedikit pun menyimpan keraguan di hati mereka terkait perilaku syirik karena secara aqidah dinilai bertentangan. Oleh karena itu, demi meraih kemaslahatan bersama (al-mashlahat al-'ammah) maka tidaklah penting mempertentangkan terselenggarakannya kegiatan adat yang dituntun dengan norma-norma agama (Islam).

\section{Kesimpulan}

Eksistensi maupun dinamika pesantren di kawasan pesisir pantai utara Jawa pada umumnya tidak bisa lepas dengan lingkungan sosial dan latar sejarahnya sebagai institusi pendidikan Islam tradisional, yang telah menampilkan corak budaya kosmopolitan di lingkungan masyarakat pesisiran yang cair. Kondisi demikian nampak dipengaruhi oleh budaya bandar di mana pelabuhan telah memainkan peranan penting tidak hanya dalam roda perekonomi akibat lancarnya pertukaran arus barang dan manusia dari dan ke berbagai tempat dan belahan dunia. Tetapi secara intens di pelabuhan juga berlangsung kontak budaya di samping adanya pertukaran ide dan perkara-perkara lainnya yang datang dari lapisan sosial dan sumber yang beragam.

Terbentuk dari latar sosio-kultural demikian yang mendorong pesantren lebih terbuka terhadap hasil inovasi (tradisi baru), misalnya mengadopsi sistem pendidikan universal pada zaman itu serta toleran dengan budaya lokal maupun manca. Didukung kemampuannya beradaptasi dan melakukan transformasi sosial-institusional sebenarnya itulah kunci sukses yang membuat pesantren sustainable dan tetap bisa mendapatkan pengaruh serta basis pendudukungnya dari berbagai lapisan masyarakat.

Dengan mempertimbangkan kalangan pendukungnya maka corak pemikiran Islam kosmopolitan senantiasa dilestarikan dan diperkenalkan kepada santri dan masyarakat luas, yaitu melalui pembudayaan literasi kitab kuning, umumnya berupa risalah mukhtashar yang mengupas ajaran tauhid, fiqh-ibadah dan akhlak. Kitab-kitab klasik tersebut merupakan karya ulama Ahlussunnah wal Jama'ah yang berotoritas dari berbagai belahan dunia Islam di samping karya ulama dari kalangan pribumi sendiri. Bagi kalangan pesantren tradisional (salafiyah), kitab kuning merupakan bagian integral daripada ciri khas lembaga pendidikan serta identitas budaya pesantren yang justru membedakan lembaga pendidikan tradisional tersebut dengan jenis-jenis pendidikan lainnya di Tanah Air.

Kitab kuning yang meliputi pokok bahasan ilmu Al-Qur'an, Hadist, fiqh, 
aqidah dan akhlak atau social-etic tentu merupakan sumber utama yang menjadi rujukan nilai dan pembentukan norma. Sumber-sumber etikal terpercaya inilah yang menjadi rujukan utama dan nilai dasar pembetukan karakter santri dengan menjadikan kiai sebagai role model. Dengan kata lain, kitab-kitab kuning adalah referensi standar manakala seorang santri (kader ulama) ingin mendalami ilmuilmu keislaman (tafaqquh fi ad-din) dan membangun kebudayaan warga pada lingkungan sosial yang berkeadaban. Wallahu 'alam bis shawab. 


\section{Daftar Pustaka}

Abdullah, Taufik, 1996. Islam Dan Msyarakat: Pantulan Sejarah Indonesia, Jakarta: LP3ES.

Ali, Fachri, 1997. Kewibawaan Pendidikan Islam sebagai Wacana Keberdayaan, dalam Muslih Usa dan Aden Wijdan AZ (Peny.), "Pendidikan Islam dalam Peradaban Industrial", Yogyakarta: Aditya Media.

Dhofier, Zamakhsyari, 1994. Tradisi Pesantren, Studi Tentang Pandangan Hidup Kiai, Jakarta: LP3ES.

Fikri, Ibnu, 2014. “Aksara Pegon: Studi Tentang Simbol Perlawanan Islam Jawa Abad Ke-XVIII - XIX", Laporan Penelitian, Semarang: Lembaga Penelitian dan Pengabdian Kepada Masyarakat (LP2M) IAIN Walisongo.

Giddens, Anthony, 1984. "The Constitution of Society: Outline of The Theory of Structuration", Cambridge: Polity Press.

Guba, E.G. dan Y.S. Lincoln, 2009. “Berbagai Paradigma Yang Bersaing Dalam Penelitian Kualitatif" dalam Denzin, N.K. \& Y.S. Lincoln (eds), Handbook of Qualitative Research. Terjemahan Daryatno, dkk. Yogyakarta (ID): Pustaka Pelajar.

Hadi, Syamsul, 2017. Arah Baru Lembaga Pesantren Dalam Kehidupan Masyarakat Desa: Idealisme Versus Pragmatisme, Bogor: Institut Pertanian Bogor (Disertasi).

Hasyim, Umar, 1974. Sunan Kalijaga, Kudus: Menara Kudus.

Horikoshi, Horiko, 1987. Kiai dan Perubahan Sosial, Jakarta: P3M.

Indrahti, Sri, 2012. Kudus Dan Islam: Nilai-nilai Budaya Lokal Dan Industri Wisata Ziarah, Semarang: CV. Madina, 2012.

Janutama, Herman Sinung, 2014. Fakta Mengejutkan Majapahit Kerajaan Islam, Bandung: PT. Naura Books Mizan Pustaka.

Kadiran, 2007. Kebudayaan Jawa, dalam Koentjaraningrat, "Manusia Dan Kebudayaan di Indonesia", Jakarta: Djambatan.

Kayam, Umar, 1989. Transformasi Budaya Kita: Makalah Pidato Pengukuhan Jabatan Guru Besar pada Fakultas Sastra Universitas Gadjah Mada pada tanggal 13 Mei 1989, Yogyakarta: UGM.

Koentjaraningrat, 2007. Manusia Dan Kebudayaan di Indonesia, Jakarta: Djambatan.

Kuntowijoyo, 2008. Paradigma Islam: Interpretasi untuk Aksi, Bandung: Mizan, 2008.

Lombard, Denys, 1981. Campa Dipandang Dari Selatan, dalam Ecole Francaise D'extreme-Orient (Pen.), “Kerajaan Campa”, Jakarta: Balai Pustaka.

Lombard, Denys, 2005. Nusa Jawa: Silang Budaya Jilid II, Jakarta: Gramedia.

Madjid, Nurcholish, 1992. Islam di Indonesia dan Potensinya Sebagai Sumber Substansiasi Ideologi dan Etos Nasional, dalam Budhy Minawar-Rachman (Ed.)

“Kontekstualisasi Doktrin Islam Dalam Sejarah”, Jakarta: Paramadina.

Madjid, Nurcholish, 2004. Indonesia Kita, Jakarta: Paramadina dan Gramedia. 
"Mengembangkan Kestrategisan Pondok Pesantren", http://pendis.kemenag. go.id $/$ index. php?a $=$ detil\& id=9405\#.YGkp9WQzbIU, diunduh pada tanggal 04 April 2021, pukul: 1020 WIB.

Meuleman, Johan Henrik, 1999. Islam Asia Tenggara dan Proses Globalisasi, dalam Jurnal: Wacana, 2(1):23-42.

Nasr, Seyyed Hossein, 1987. Traditional Islam in The Modern World. York New. Columbia University Press.

Nugroho, Iwan Santoso, 2011. Majapahit Pedaban Maritim, Jakarta: Yayasan Suluh Nuswantoro Bhakti.

Nugroho W. Uji, 2016. “Arti Penting Pesisir Dalam Mewujudkan Indonesia Sebagai Poros Maritim Dunia", dalam, Bunga rampai Lawatan Sejarah Nasional: Menelusuri Jejak Sejarah Maritim di Pantai Utara Jawa Tengah (Ed. Darto Harnoko), Yogyakarta: Balai Pelestarian Nilai Budaya (BPNB).

Ricklefs, M.C. 1989. Islamisasi di Jawa: Abad ke-14 Hingga ke-18, dalam Ahmad Ibrahim, "Islam Asia Tenggara: Perspektif Sejarah", , Jakarta: LP3ES.

Shihab, Alwi, 2002. Islam Sufistik, Bandung: Mizan.

Solichin Salam, 1977. Kudus, Purbakala Dalam Perjuangan Islam, Kudus: Menara Kudus.

Sulistiyono, Singgih Tri, 2017. Peranan Pantai Utara Jawa Dalam Jaringan Perdagangan Rempah, Makalah disampaikan pada Seminar Nasional mengenai Jalur Rempah dengan tema "Rempah Mengubah Dunia" (Makassar: 11 - 13 Agustus 2017).

Sunyoto, Agus, 2011. Wali Songo: Rekonstruksi Sejarah yang Disingkirkan, Jakarta: Transpustaka.

Swie, Tan Khoen, 1936. Serat Babat Thuban, Kediri: Toko Buku Than Khun/Hing.

Tan, Charlene, 2014. Educative Tradition and Islamic Schools in Indonesia, Nanyang Technological University, Singapore. Journal of Arabic and Islamic Studies-14 (2014), p. 47-62.

van den Berg, L.W.C. 2010. Orang Arab di Nusantara, Depok: Komunitas Bambu.

van Bruinessen, Martin, 1995. Kitab Kuning, Pesantren Dan Tarekat: Tradisi-Tradisi Islam di Indonesia, Bandung: Mizan, 1995.

Wahid, Abdurrahman, 2007a. Islam Kosmopolitan: Nilai-nilai Indonesia dan Transformasi Kebudayaan, Jakarta: Wahid Institut.

Wahid, Abdurrahman, 2007b. Menggerakkan Tradisi: Esai-esai Pesantren, Yogyakarta: LKiS.

Zamjani, Irsyad dan Faishal A. Muhammad. 2004. "Islam Jawa Pesisir(an); Sekedar Teorisasi Sejarah", Jurnal: Afkar, Edisi No. 17 Tahun 2004.

Zuhri, Saifuddin, 1981. Sejarah Kebangkitan Islam dan Perkebangannya di Indonesia, Bandung: PT. Al-Ma'arif. 
98 | Tradisi Pesantren dan Kosmopolitanisme Islamdi Masyarakat Pesisir Utara Jawa

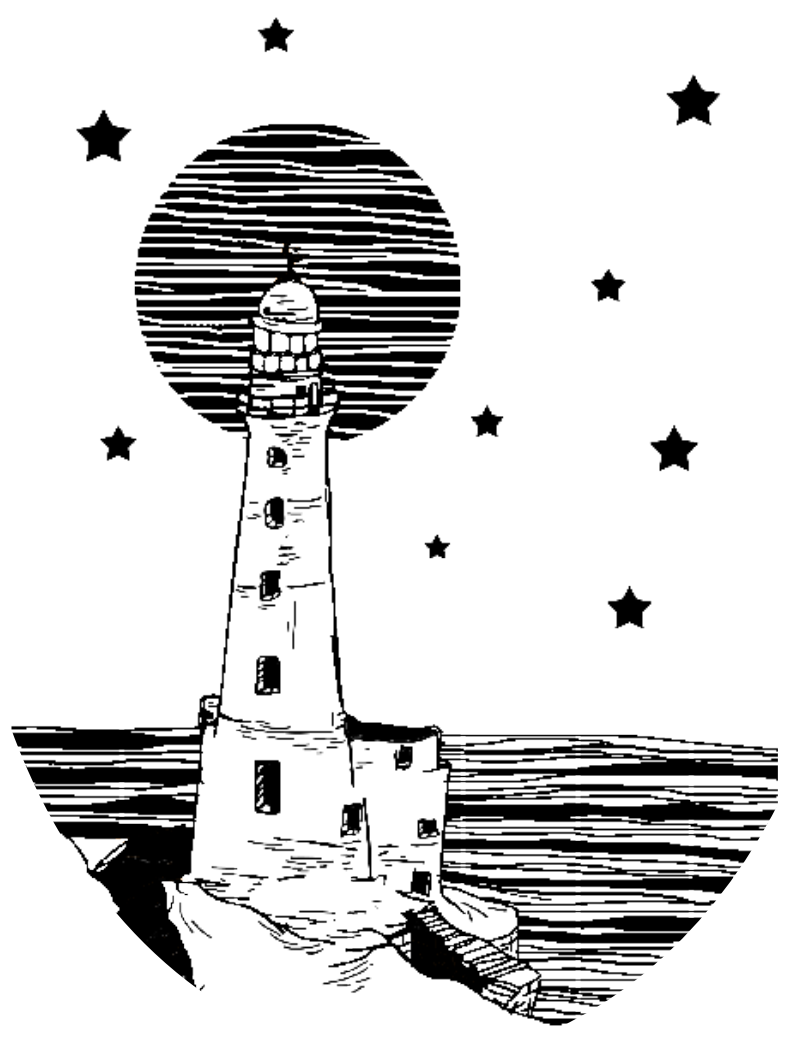

